\title{
Foucault's Concept of Heterotopia as an Èpistemé for Reading the Post-Modern City: The Viennese Example
}

\author{
Gerhard Hatz \\ Department of Geography and Regional Research, Universitaet Wien, Vienna, Austria \\ Email: Gerhard.hatz@univie.ac.at
}

How to cite this paper: Hatz, G. (2018). Foucault's Concept of Heterotopia as an Ėpistemé for Reading the Post-Modern City: The Viennese Example. Current $U r$ ban Studies, 6, 455-482. https://doi.org/10.4236/cus.2018.64025

Received: July 11, 2018

Accepted: November 10, 2018

Published: November 13, 2018

Copyright $\odot 2018$ by author and Scientific Research Publishing Inc. This work is licensed under the Creative Commons Attribution International License (CC BY 4.0).

http://creativecommons.org/licenses/by/4.0/

\section{(c) (i) Open Access}

\begin{abstract}
"The postmodern city is a myth, a tale, a telling, a poignant narrative that builds on the past to continually new horizons... The postmodern city is not only an epitomizing model of contemporary social and economic development, but also a metaphysical reality, a place where the real and the imagined are persistently commingled in ways we have only begun to understand..." (Chambers, 1990; Soja 2000). Normative notions on the city have to be dissected as an intersection of the near and the far order of urban societies (Lefebvre, 1996) and as fluid conceptualizations in a heterochronical context. However, cities similarly have to be read as "thirdspaces" (Soja, 1996) - contestations of mythical and real urban spaces and places, continuously re-interpreted and endowing urban spaces and places with even transient meanings. The paper seeks to grasp Foucault's notions on heterotopia as a theoretical framework and èpistemé for approaching these "thirdspaces"-in-between the social relations and their inscriptions into the material reality of cities.
\end{abstract}

\section{Keywords}

Urban Theory, Ėpistemé, Heterotopia, Vienna, Foucault

\section{Locating Heterotopias-A Mythical Contestation of the Near and Far Order of Urban Society}

Approaching "thirdspaces" of cities implies locating these thirdspaces within the relational context of the near and far order of societies and its material re-presentations. Following Lefebvre the near order is defined by the relation of individuals in groups or the relation between groups. The far order is that of society, regulated by powerful institutions, formalized by legal codes and/or a cul- 
ture. The far order projects and writes moral and legal principles into the near order and the material reality of the city. The compelling power of the far order that "persuades through and by the near order" (Lefebvre, 1996: p. 101) follows the rationale of a dispositif as examined by Foucault: Power relations constitute a network that is constructing and shaping discourses, belief systems and hegemonies, eventually spanning the matrix of a dispositif. According to Foucault a dispositif is constituted by an intertwined heterogeneous ensemble of discursive and non-discursive elements as institutions or architecture. The dispositif is the relation among these elements, having a dominant function in terms of intended and unintended strategies. Inherent contradictions and unintended effects are re-interpreted and re-integrated, leading to new strategies.

Hence, a dispositif is a fluid relation of power, knowledge and space that is continuously negotiated. In the rationale of Foucault, space is fundamental in any exercise of power. Urban planning schemes constitute a dispositif-in relation to space, one among other dispositifs (Pløger, 2008; Dahlmanns, 2008), for instance on social or environmental sustainability. Regarding urban planning, it reveals itself as a technology of power: Imposing visions on urban spaces symbolizes who belongs to specific places. Dispositifs are the agenda settings and agenda framings of notions on the city and how they are transposed in the urban form. Connections can be made between the rationale of a dispositif and Lefebvre's notions on the "urban".

Lefebvre (1996) distinguishes between the "city" and the "urban". The "urban" represents the social reality, made up of relations which are constructed or reconstructed by thought - a kind of imaginary transcendence. As a placeless place, the "urban"- the urban life, the urban society, is inextricably linked to the immediate material and architectural reality of the city. If the "urban" cannot be inscribed into the material reality of the city, e.g. planning thoughts, it is bound to disappear.

The relation between the urban and the city bears similarities to the concept of heterotopias as examined by Foucault (1986). The rationale of heterotopias is grounded on utopias-relations of representations of a perfected form of society with the real space of society. Still, utopias are unreal spaces. When transferred into real space, urban utopias are becoming transposed as heterotopias, "effectively enacted utopias ... a sort of simultaneously mythical and real contestation of the space in which we live..." (Foucault, 1986: p. 24).

Dispositifs form the "imaginary transcendence"-the intangible meanings of heterotopian spaces. Meanings attached to spaces and places are essential in the concept of heterotopias. Heterotopias can be endowed with one or more, even different meanings. These meanings might change over time, even disappear: "...heterotopias can change in function and meaning over time, according to the particular 'synchrony' of the culture in which they are found" (Soja, 1996: p. 160). When their meanings are becoming obsolete or disappear, heterotopias 
dissolve, eventually leading to new dispositifs that shape new meanings-utopias of the urban and new urban heterotopias. The following sections aim at dissecting the urban form of Vienna targeting to identify heterotopian traits that make up the thirdspaces of the city.

\section{Dispositifs and Heterotopias of ...}

\section{1. ...Modernist Urban Planning Schemes}

In Vienna, like in many other Metropolitan Areas in the Western Hemisphere the dispositif of urban planning schemes has continuously been re-shaped.

The dispositif shaping modernist planning schemes has to be read in its heterochronical context by referring to the unpleasant experiences of the pre-modernist city that did not match the far order of modern urban society, the Fordist mode of production and urban life-styles. New technologies, in particular the rise of the automobile, were incorporated in the planning visions of the modernist city, jettisoning all historic types and forms. As proposed by the Charter of Athens (CIAM, 1933), a clear separation of urban functions for work, residential purposes and leisure was to overcome and eradicate the undesirable living conditions of the pre-modernist city (Hebbert \& Sonne, 2006: p. 6). Urban planning in Vienna complied with the rationales of modernism as suggested by the Charter of Athens. Large social housing estates were built at the urban fringes, enabling low-income households, among those families with children, to leave the substandard housing stock characterized by small one-or two room apartments without running water or toilet inside (see Figure 1 and Figure 2).

When relocating to the newly built social housing estates the housing standard and quality of living improved considerably for those residents. The densely

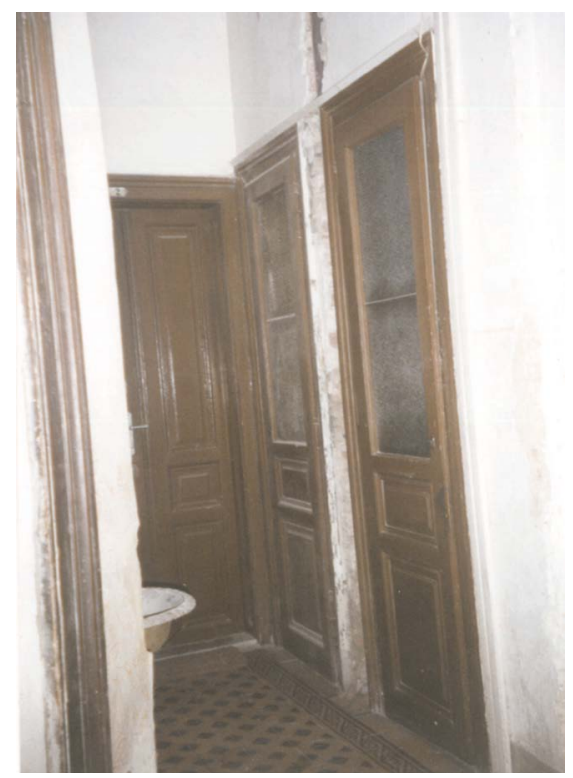

Figure 1. Substandard apartment with water supply (left) and WC (right) in the hallway outside the apartment. 


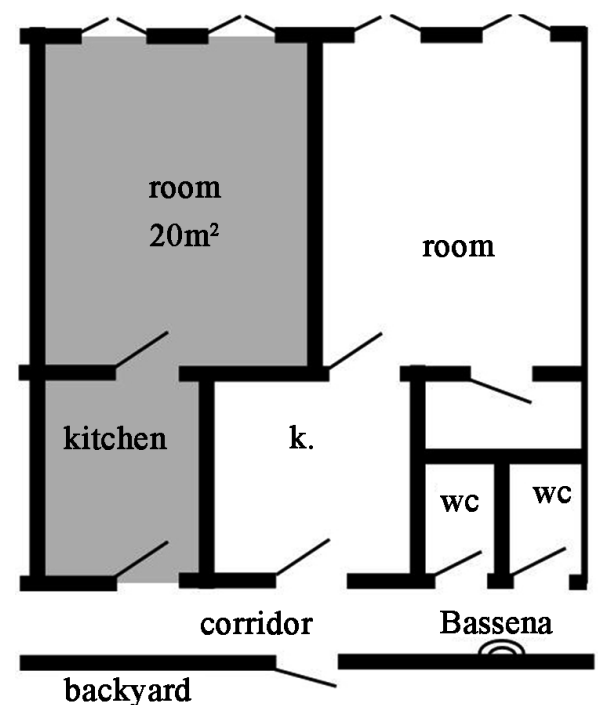

Figure 2. Floor plan of a typical substandard apartment, with water supply (Bassena) and WC in the hallway and not en-suite.

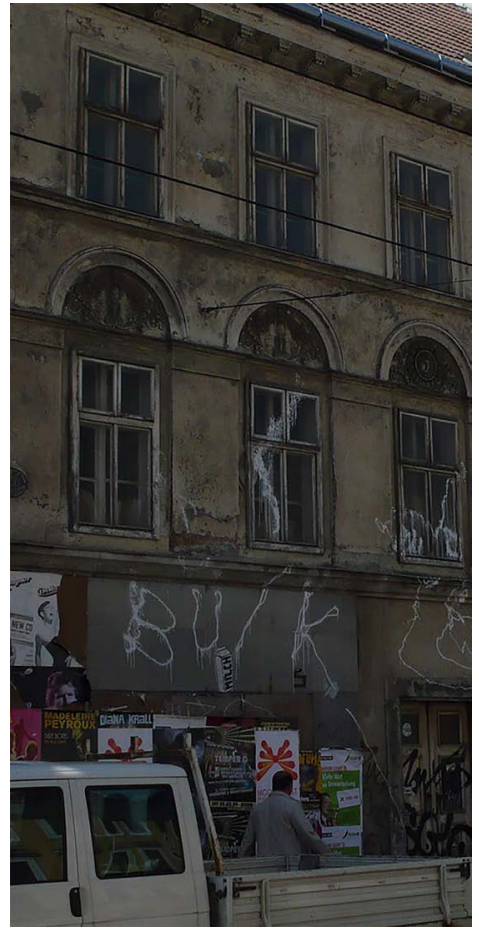

Figure 3. Substandard apartment building in the densely built up area of the inner city (copyright: C. Lippl).

built-up drab neighborhoods (Figure 3) and crowded flats were traded for green spaces and playgrounds for the children (compare Figure 4 and Figure 5).

As a consequence of the exodus to the housing estates or to suburban areas the substandard apartments in the inner city were increasingly becoming vacant and subject to either being torn down or to refurbishment and remodeling and have eventually moved into the focus of the dispositif of an urban renaissance 


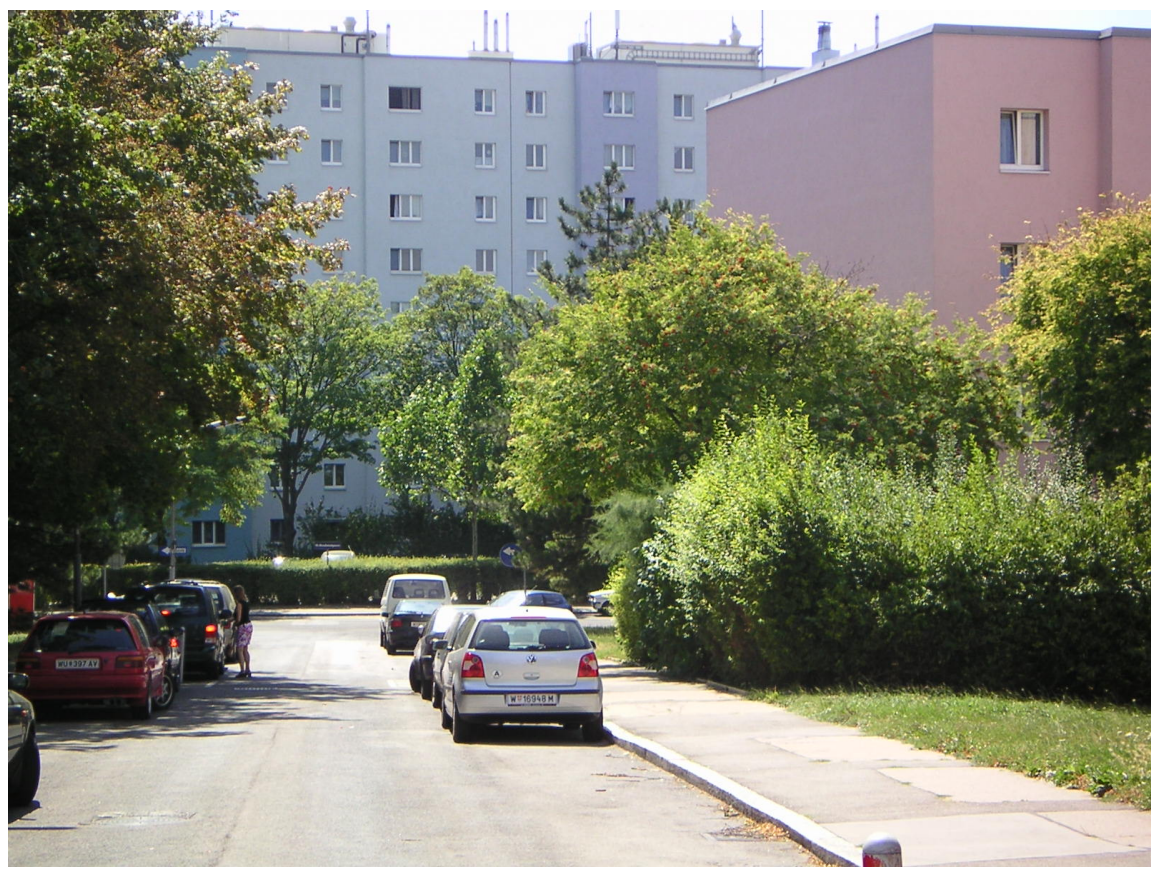

Figure 4. Social housing estate at the urban fringes (copyright: D. Schoenbichler)

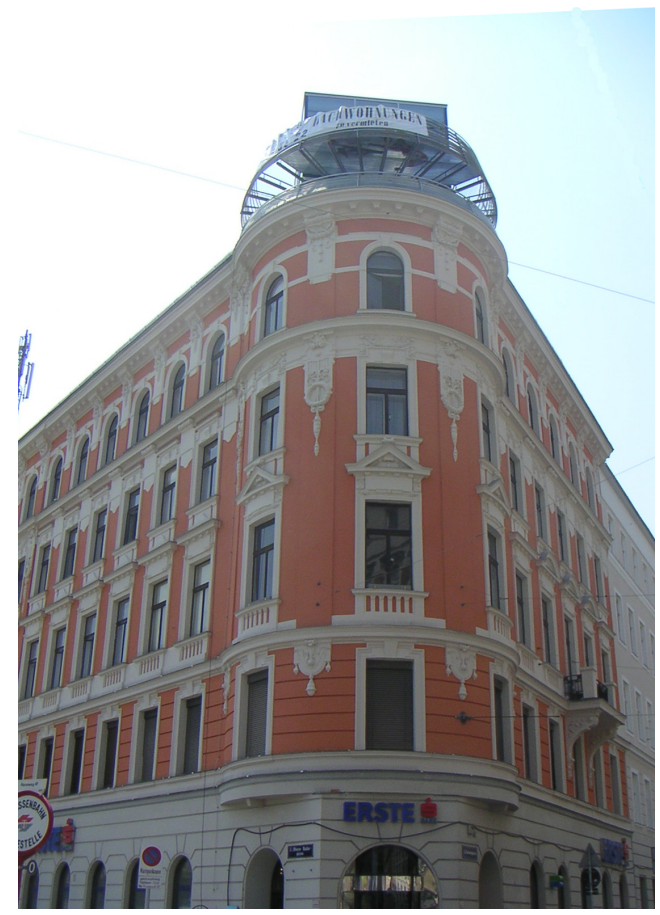

Figure 5. $19^{\text {th }}$-Century Apartment House: renovated and expanded attic (copyright D. Schoenbichler).

resulting in extensive and rather successful remodeling programms. The transformation of the social fabric in the affected neighborhoods was contained in the transformation of the far order of society. The dismantled social fabric in the inner city precincts could not be re-established in the modernist housing 
schemes, becoming replaced by the near order of the post-modern society. Nowadays these housing estates seem to have lost their meanings in relation to the inhospitable experiences of the pre-modernist urban precincts and have become the Viennese version of "non-places" according to the notions of Augé (Augé, 2008). The modernist "myth" attached to these estates has been replaced by implementing technologies of surveillance and control to maintain at least a minimum of livability in these deprived neighborhoods. Vandalism, conflicts between residents and violence in these areas indicate the emotional and affective alienation of the residents from their immediate living environment. The Heterotopia of modernist urban planning schemes dissolved and became a non-place for residents, planners and urban theorists alike (see Vorauer \& Matznetter, 2009).

\section{2. ..U Urban Renaissance}

Resulting from the shortfalls of the modernist's heterotopias, new dispositifs shaped the far order of the post-modernist city. Implementing "a human scale", "architectural and social diversity", "social life between buildings" (Gehl, 2011) or fostering creative activities have become prime agenda in the urban discourse. Scholars advocated concepts of mixed used, walkable and safe urban spaces and controlled diversity (Lefebvre, 1996) and eventually the reconstruction of social life and the social fabric in urban precincts. Heterotopias of modernist planning schemes were considered as reasoning for alienation and disembedding of urban societies. The dispositif of the Modern Movement, imposed on the urban form has morphed to the production of emotional space settings. Not surprisingly, it was at this paradigmatic turn when Foucault conceptualized his notions on heterotopias in 1967.

Heterotopias of an "Urban Renaissance" became associated with the sphere, the oeuvre of a romanticized historic interpretation of the urban, echoing "past traits that have seemingly been lost" (Allen, 2006: p. 442). The dispositif shaping the normative notions on urban planning schemes advocated the production of "urban spheres" where residents find identity and feel "at home". Visual strategies and regulations on the aesthetics e.g. as formulated in the Charter of the new urbanism (see Leceese et al., 2000), gained power and have been implemented in suburban as well as in inner city areas. Their objectives have moved on to the production of ambience and emotions juxtaposing the far order of society. The aesthetic quality of the neighborhood in terms of preserving and re-establishing romanticized historic neighborhoods was in sync with the transformation of the urban society into an individualized life-style society, the shift from Fordist modes of production to post-Fordist modes of production, the cultural values of city-dwellers and their desire for neighborhoods evoking a sense of belonging and identity. The apartment as ambient lifestyle capsule of households was extended to the neighborhood. The concept of ambient urban spheres implicitly entered urban planning schemes. 
The production of ambient quality spaces in Vienna can be traced back to the overlapping cycles of modernist urban planning and urban renaissance. Starting in the 1980s, the dispositif constituting urban renewal was reinterpreted by the narratives that imposed a romanticized meaning on the historic urban ambience. Still, the dispositif of urban renaissance had to be inscribed in the historic building fabric. The City of Vienna launched an ambitious soft urban renewal program, targeting the preservation and improvement of the historic ambience in the inner districts, improving the housing quality and ensuring the social sustainability of the renewal process (see Figure 5). Between 1984 and 2003, the more than 210,000 apartments renovated and remodeled comprise about one quarter of the entire apartment stock in the city (see Hatz \& Fassmann, 2006). The dispositif of social sustainability was redirected from the provision of social housing schemes at the urban fringes to the inner city.

However, the dispositif of a vivid quality of social spaces promoting the social fabric of the neighborhoods could not be inscribed in the heterotopias re-presenting the meaning of an urban renaissance. Public spaces as the streets and plazas in the redeveloped neighborhoods did not serve as social spaces anymore. Small shops and cafes as places of encounter and socializing closed down, replaced either by fast food chains and chain stores, apartments or garages. Small manufacturing firms vanished and so did the meaning of a lively mixed used urban neighbourhood. The meaning of the streets as places for social gatherings disappeared and was replaced by a homogenized and globalized ambience of gentrified neighborhoods, approaching heterotopian spaces of an eliterian aesthetization of the mundane. By this fission between the look and feel of these spaces and the social connectedness, the meaning of authenticity in terms of rooting the individual "in a singular time and place to a cosmic grasp of larger social forces that remake our world from many small and often invisible actions" (Zukin, 2010: p. 220) dissolved. Alienation and disembedding as a characteristic trait of post-modern societies was accentuated by dissolving connections that linked the heterotopian spaces to each other and with the "grand narrative" of the city. The loss of belonging and identity to a unique and original city has been reinforced by disintegrating the urban form and dispositifs in distinct spheres of individualized constructions of the self (see Beck et al., 1995) in the globalized city.

\section{3. ...The Globalized City}

At the turn of the Millennium the impact of de-industrialization and the emerging globalized economies reshaped the far order of urban society. The number of work places in manufacturing had decreased in Vienna since the 1970ies. Industrial sites lost their functions and their meanings, eventually falling into decline. The heterotopias of the industrial city were dissolving and disappeared transforming the sites into "waiting lands" (Christiaanse, 2002)—waiting for a new "urban" meaning, then a new function attached to the sites (see Figure 6). 


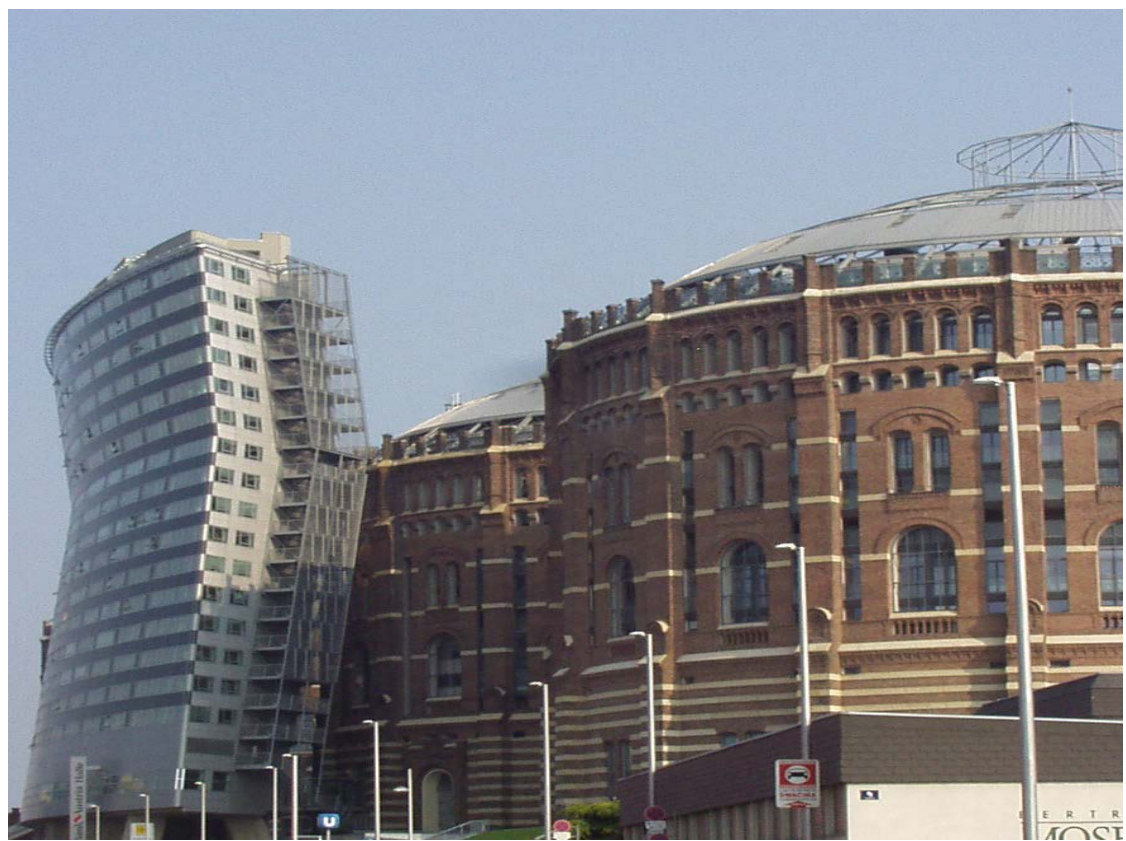

Figure 6. Office spaces and apartments implemented in an abandoned gas works plant.

The city had to adapt according to the far order imposed by the globalized economies that could neither be transposed into the historic precincts of the inner city nor in the homogenized remainders of modern urban planning schemes. Following the planning scheme of the compact, poly centered city, new urban centers emerged or were implemented into abandoned brownfield sites.

As a spatial interface, the redeveloped brownfield areas projected the heterochronical relations of urban renaissance and planning for the globalized economies, contextualizing the near and far order of the globalized city. The sites became emanated with particular meanings, embodying new visions of urban lifestyles. Terms as "Loft Living" or "Live and Work" represented a new culture of a first avant-garde, later on a bourgeois urban lifestyle. The pristine function of the site became inverted and attached with the "myth", theme or narrative of an alternative urban life-style. Redeveloped brownfield areas have been transformed into ambiences loosely interconnected to other sectors of the city and other redeveloped brownfield sites by mass rapid transit system. The sites are attached with a theme that occasionally refers to the former uses like "Tobacco Factory", "Cable Factory", "Brewery" or "Gasometer-City". The historic building fabric was re-used as a signifier of the new dispositif, attaching a meaning and identity to the site and enhancing the ambient quality of the site in terms of architectural diversity.

In new urban centers the far order that shapes the postmodern society and recent urban discourses is represented by providing mixed used urban environments, providing car-free, walkable but city-like environments in terms of enclosed office spaces, shopping malls and apartments. Meanings have been attached to the housing estates by labeling them as "residential parks", later on by 
dedicating individual residential buildings to specific themes or lifestyles, like "Hanging Gardens", "Living at the Golf Court", etc. New urban centers and redeveloped brownfield sites have become the "all-in heterotopia" (Dehaene \& De Cauter, 2008b: p. 7) of a globalized but individualized life style society.

\section{4. ...The Eco-Sustainable City}

Since the turn of the Millennium the dispositif of ecological sustainability has reshaped the dispositifs of urban planning schemes. For Vienna the idea of eco-sustainability currently refers to the smart use of natural resources to assure that these resources will still be available in the long-term. Sustainable urban development is aimed at avoiding to exploit, waste and exhaust natural resources, and to guarantee their availability for future generations. Ecological sustainability according to Vienna's recently approved Masterplan focuses on climate protection and the preservation of biological diversity (see Stadtentwicklung Wien, Magistratsabteilung 18, 2014: p. 23ff.).

Like the issue of social sustainability the dispositif of ecological awareness has been affiliated with transient meanings. When modern urban planning was guided by the dispositif of "reconquering the sun" (Le Corbusier) (see Siret, 2006) and providing open green spaces in urban settlements that were at odds with the congested densely built up inner city precincts, the ecological dispositif of urban planning was reinterpreted. Urban Renaissance, focusing on the idea of a compact city, was, among others, to reduce the waste of land reserves by urban sprawl and the negative impacts of increasing car traffic. By promoting walkable and car free urban environments the dispositifs of reconquering the social spaces in the city and environmental preservation came together. At the turn of the Millennium the issue of global climate change shaped the dispositif of low carbon cities. Zero energy architecture and ecological sustainability attached new themes to new urban sectors and life styles. The playful eclecticism of post-modern architecture is now being replaced by a new "low carbon" functionalism, re-shaping urban design and the urban form. Energy efficiency determines architecture and the design of buildings and urban neighborhoods, re-defining the meanings of heterotopias representing the dispositif of the eco-sustainable city. The functionally designed low or zero energy urban fabric is endowed with the new meanings by labeling it with ecologically sustainable life style terms such as "Car Free City", "Bike City", "Ville Verdi", "Monte Verde", etc.

\section{5 "Non-Places" and Voids}

Modernist urban planning, just like previous urban utopias, was to impose a comprehensive meaning and utopia on urban planning schemes and to remove the remains of dissolving heterotopias of previous urban development. Since then the cycles of dispositifs projecting utopias of urban form and societies have accelerated, each of which focusing on particular urban sites that were either reinter- 
preted or had to be newly constructed, eventually resulting in fragmented patterns of urban planning. Hence, in between the sites that morphed into heterotopias of recent urban societies, urban areas lost their meanings, eventually turning into voids for urban planners and residents alike, now becoming re-presentations of non-places. In Vienna the remainders of modern urban planning such as social housing estates at the urban fringes, but even low quality apartments in the inner city not affected by the soft urban renewal program have become such voids, having turned into the areas where the powerless urban residents, such as low income or immigrant households are concentrated. Even though these groups attach their own meanings to the sites, they do not follow the mainstream of urban planning and the prevailing dispositif of the recent city.

\section{The City-A Meta-Collector of Transforming Heterotopias}

The far order of post-modern urban societies, marked by individualization, diversification of households and lifestyles, in sync with intertwining physical manifestations of prevailing previous heterotopias, has transposed the urban form into poly-atmospheric ambiences-representations of temporary, emergent and transitory heterogeneous heterotopias. Still, the spatial dispositifs on the urban form are fractured by dispositifs shaping the discourses on social sustainability, culture, heritage and identity, modes of production or environmental protection. Related concepts of the "urban" that emerge out of these dispositifs all come together and physically manifest themselves in their spatial representations, inscribed in the material reality of the city. The city dissolves in fragmented patterns of transforming heterotopias. Scholars refer to the recent urban conditions in terms of: "Island urbanism, resulting in a fragmented patchwork of physically disconnected unfinished parts within the urban area" (Novy et al., 2001; Oswalt, 2006). Implicitly Wigley in 2001 anticipates the form of the recent city in terms of a foam collecting ephemeral bubbles or spheres of heterotopian spaces.

"Instead of cities being determined by pre-planned structures, they are revealed as amorphous, ... indeterminant sites, ... they are temporary, emergent and transitory, ... an endless world made up of tightly interconnected but heterogeneous spaces" (Wigley, 2001: p.11).

As it seems, Foucault anticipated in his notions on heterotopias the fracture and time-distance compression of urban spaces and places: "We are in the epoch of simultaneity... in the epoch of juxtaposition, ... of the near and far, of the side-by-side, of the dispersed" (Foucault 1986: p. 22). Thus, he implicitly conceptualized the èpistemé for reading the topology of the contemporary city as a "Meta-collector" of transforming heterotopias. Connections can be made to the notions of the German philosopher Peter Sloterdijk, re-interpreting the social order and its spatiality in terms of spheres of coexistence. The multifocal, multi-perspectivist, and heterarchic condition of urban societies is becoming inscribed in the material reality of emerging Foam Cities.

In his rationale of "Foam Cities" Peter Sloterdijk points at the topological 
characteristics of contemporary cities and draws on the near and far order of the individualized urban society in terms of "connected isolation", which is projected at the level of apartments, housing estates and settlements (Sloterdijk, 2004: p. 257). The notions of Foam Cites focus on the prime function of the city as a site of assemblage. The Foam City is a site of collectors addressing the three poles of urban life-work places, housing and spaces for collective assemblies, linked with each other by transport and communication infrastructure. The characteristic trait of the Foam City is the agglomeration of atmospheres of unique urban space settings-a "foam" of urban spheres, each of which re-presenting one or more specific traits of heterotopias. The urban macro foam has to be read as a Meta-Collector, collecting heterogeneous concepts of emerging and dissolving heterotopias. The co-existence of centers and non-centers, not as a superimposed center but as an agglomeration or a piling up of a discrete spatiality of the types: collector, business, apartment and designed public spaces as material intersections of the heterarchic far order of recent urban societies. The current city that has emerged as a meta-collector does not refer to the individuals either assembled or isolated-or the apartments of the individuals-but to spaces as invented space settings.

In these inventions of space settings individuals might make use of the options of co-existence-or not and might make use of options to interact-or not. New urban realities and urban spaces are made up of constructed installations of atmospheres and environments, each of which re-presenting a specific inscription-in their "vertical" relations to the near and far order of the city and in their horizontal relations of interconnecting invented space-settings of specific representations of heterotopologies at the micro- and meso-level of the city.

\section{The Meaning of Historic City Centers as a Perfected Form of Heterotopia in Emerging Foam Cities}

As the city reveals as a Meta-Collector of emerging and dissolving heterotopias, still unfinished and imperfect, this points to the mythical trait that connects and integrates the heterotopian spheres of these Foam Cities. The mythical trait represents the identity of the city and a collective sense of belonging to the city as an entity at the macro-level collecting and assembling the fragmented heterotopian spheres. Following Lefebvre the mythical trait of the transcendent identity of the city has to be inscribed in the material reality, projecting the oeuvre, and the perfected symbolic re-presentation of belonging with the city. Connections can be made to the concepts of "belonging" and heterotopian spaces. Following Savage et al. (2005) belonging has become prominent in the urban discourse by transforming the far order according to the dispositif that was imposed by globalization on urban societies. The idea of "selective belonging" associates senses of spatial attachment in relation to the connectivity to other places. In this vein "belonging" is a fluid relation to sites for performing (individual) identities (Savage et al., 2005: p. 29f.). Foam Cities collect or assemble 
these heterotopias of individual identities at the micro level e.g. the apartment or at the meso-level of urban precincts representing the identities of gentrifiers or ecologically sensitive city dwellers. Following this line, belonging to sites that represent the identity of the macro foam assembling heterogeneous heterotopias induces a perfected form of heterotopia- a site in relation to all other heterotopian spaces that make the foam city-for performing and representing the symbolic identity of the meta-collector.

In fragmented post-modern urban environments, city centers have become the re-presentations of universal spaces of belonging, to be understood in their set of relations with other spaces. The meaning of place and belonging is less associated with "face to face" contacts "but in terms of their networked relationships with other locations" (Savage et al., 2005: p. 106). City centers rather than immediate neighborhoods are identified as the spatial re-presentations of belonging of city dwellers as well as of the residents in the suburban areas. Culture, in particular high culture, just like related cultural activities are the characteristic traits attaching city centers with feelings of sense of belonging. As idealized representations of belonging, city centers are perceived as "other spaces", distinctive from the everyday spaces. City centers are experienced as a "world apart" from the normal, ordinary daily life and associated with meanings of "sacred" and "mythical" places enhancing an auratic character of a "special" place, removed from the daily routines (Savage et al., 2005: p. 122). Escapism seemingly is one of the seminal features of these places. Transposing the notions of Foucault on heterotopias, escapistic places are "formed in the very founding of society" (Foucault, 1986: p. 24). The "mythical" and "sacred" contexts and affiliations of spatial entities invoke a theoretical framework for reading the urban form as a mediator of the mythical and real contestations of the space we live in in terms of mythical and real contestations of belonging.

\subsection{The Mythical, Transcendence Trait-Towards a Universal Form of Heterotopia}

"Mythification" of spaces and places is a seminal feature of heterotopias just as in the concepts of belonging. Hetherington notes that "modernity moralises place through the generation of diverse place myths, utopias and heterotopias" (Hetherington, 1997: p. 79). In the rationale of Foucault, space in contrast to time is not desanctified yet. The still prevailing fissions between "private and public, family and social space, cultural and useful spaces" and between spaces for work and leisure reveal the "hidden presence of the sacred" (Foucault, 1986: p. 23). Foucault delineates heterotopias as spatial mediators of utopias and "real" space. Urban utopias imply visions on a perfected form and the transcendence myth of society. As the Swiss writer Max Frisch puts it: "Without utopias we would be creatures without transcendence" (Max Frisch, cit. in Der Spiegel, 1991: p. 264). Heterotopias as transposed spatiality of utopias are "a sort of simultaneously mythical and real contestation of the space in which we live" 
(Foucault, 1986: p. 24). In emerging Foam cities (historic) City centers seemingly comply with perfected spaces of belonging, affiliated with even mythical and sacred meanings. The relations of meanings just as the physically experienced (visual) relations take on an "almost mythical quality" (Savage, 2005: p. 122).

Symbolic perfection is an intrinsic feature of mythical and transcendent signifiers. In his rationale of heterotopias Foucault denotes a conceptualization of "real and unreal urban spaces ... onto which the whole world comes to enact its symbolic perfection" (Foucault, 1986: p. 24). The intrinsic function of heterotopias is their relation opposite the fracture of urban societies and the fragmented urban "macro-foam". "... a space of illusion that exposes every real space, all the sites inside of which human life is partitioned...”, and, “... to create a space that is other, another real space, as perfect, as meticulous, as well arranged as ours is messy" (Foucault, 1986: p. 27).

In the concept of cities as Meta-Collector of transforming heterotopias city centers, in particular historic city centers, are becoming attached with a different meaning. The traits that signify the city center as a space for "special reasons" opposite to spaces for "day-to-day business of life" have been dissected by Savage et al. (2005): The meaning of city centers serves as a "key symbolic marker" for the dwellers of post-modern Foam Cities. City Centers collect heterotopias that refer to "high culture", condensing the symbolic-hence cultural meaning of the Meta-Collector. Savage et al. (2005) point out the meaning of city centers that is not so much related to the actual usages of the space but more related to "visual" and "auratic" relations, making the city center a "common reference point" for residents in diverse places in the heterotopic realm of Foam Cites (see Savage et al., 2005: p. 130).

Heterotopias have to be understood in their relations to other spaces and places and have to be read in the set of relations of meanings. As perfected places heterotopias "have the ... property of being in relation with all the other sites, but in such a way as to suspect, neutralize, or invert the set of relations that they happen to designate, mirror, or reflect" (Foucault, 1986: p. 24). Conceived and experienced relations are pivotal in the conceptualization of heterotopias as these relations are decisive features in the conceptualization of belonging: “... we build on the argument that people's connections-both imagined and lived-to other places, are fundamental to their sense of belonging" (Savage et al., 2005: p 106).

Referring to the initial question the following sections seek to deploy Foucault's notions on heterotopia for grasping auratic traits and symbolic values and meanings of urban spaces. The dissection of the historic city center of Vienna is grounded on the assumption that approaching a universal form of heterotopia makes the city center a central hub in the foam of emerging and dissolving but imperfect heterotopias.

Heterotopias can come in various shapes and forms, however, it has to be expected that there are no universal forms. By describing the traits and formulat- 
ing six principles of heterotopias, Foucault implicitly argues that the more traits and principles apply to particular spaces, the more are the spaces approximating to the universal form of heterotopias or highly heterotopic places

The dissection of the Historic City Center as a perfect place of belonging follows the six principles of heterotopias as formulated by Foucault.

\subsection{First Principle: Distinctiveness}

The main characteristic of heterotopias is their distinctiveness to other places, defined by the "normal" and "ordinary" meanings of everyday life (see Dehaene \& De Cauter, 2008a). Even if evoking senses of belonging is related to "everyday" routines, the spatial connection of feelings of belonging is related to the distinctiveness of specific sites that makes them different from the normal, everyday spaces. However, it is not just the physical characteristics that make these spaces stand out in relation to all other places, it is the meaning of these places in their relation to the meanings of (all) other places. Deviation from the "norm" is the common denominator that makes heterotopias distinctive from other places. When Foucault identifies heterotopias of crisis or heterotopias of deviation in terms of deviant behavior, "heterotopias now realize or simulate a common experience of place. ... Today heterotopia, from theme park to festival market, realizes 'places to be' in the non-place urban realm" (Dehaene \& De Cauter, 2008b: p. 5). In this vein Savage et al. (2005) identify distinctiveness of uses, activities, occasions and visuals as common denominator of "universal" sites of belonging, superimposing distance relations and social relations in terms of face-to-face contact. When transposed to Foucault's rationale, "universal" sites of belonging unfold as heterotopias, essential in developing and evoking senses of belonging.

In the city center of Vienna, the capital of Austria, the political and economic power in the country as well as an abundance of important architectural symbols tied to Austrian identity are concentrated. St. Stephen's Cathedral, the Imperial Palace and the State Opera House are buildings that can be seen as parts of the symbolic capital of the country. As representative space not only the concentration of architectural symbols reflecting Vienna's and Austria's entire history makes this space distinctive from all other spaces of the city. The city center is the priciest location within the city. Apartment prices of approx. 10,137€ per $\mathrm{m}^{2}$ in 2018 are the highest in Vienna, three times more than the city's average (immopreisatlas.at, 2018). With $48 \%$ of the residents holding a university degree in 2015 (city average: $25 \%$ ) it is also the center of the social "and academic elite". But the historic city center serves as the functional center of the entire city as well. More than 111,000 employees (13\% of the entire workforce of the city), $25 \%$ of employees of government institutions and about $17 \%$ of the work places in finance and insurance businesses are concentrated there (Statistik Austria, 2011). Despite the proliferation of new spaces of consumptions and the suburbanization of retailers and consumers, with about 226,000 square meter sales area the city center is still at the top of the retail hierarchy of the city (Hatz, 
2010). The city core still is the uncontested center of the city and an exceptional space in relation to all other sites. Still, it is also the use of the space just like specific planning regulations imposed on the historic city center that are unique in relation to other places in the city.

The "otherness" of the city center and its "universal" symbolic meaning of belonging are becoming visible in a survey of about 1000 Austrian visitors to the city center (IFES, 2009) and a follow-up study of about 500 students in Vienna (Hatz \& Kreppenhofer, 2012). By analyzing the student's mental maps, the city of Vienna is perceived primarily through the city center and its symbolic representations. The more distant from the city center, the more the image of the entire city of Vienna is dissolving. Even new architecture such as striking highrises in new urban centers at the borders of the densely built up area, symbolizing a modern and dynamic city, are not represented in the mental maps, implicitly indicating their insignificance as signifiers of belonging.

Distinctiveness and exclusivity in relation to the "normal" and "everyday" are decisive features for evoking senses of belonging. By using explorative factor analysis the underlying dimensions of uses and functions for the sample of students in that survey have been extracted. For these respondents the city center serves as a site for collective assemblage and is used as an exclusive site for performing an exclusive life-style. Implicitly the uses listed by the respondents in this survey refer to the construction of personal, social, cultural and spatial identity. The city center is used for meeting friends, window shopping and shopping-part of constructing the self and social identity (Hatz \& Kreppenhofer, 2012). Scholars (Savage et al., 2005: p. 116; Zukin, 1995; Zukin, 2005) agree that consumption has become not only a means to attract people to the city's core but in particular conspicuous consumption has morphed into an integral part of the individual's definition of the self. When linked to space, conspicuous consumption has moved on to the consumption in and of spaces, which constructs the consumer's identity, and eventually, when related to space, connects the consumer and the spaces of consumption by a sense of belonging. Using the city center for cultural activities points at the formation of cultural identity-and belonging and in this vein "sightseeing" relates to the formation of cultural identity and identity and belonging of and with a site (Hatz, \& Kreppenhofer, 2012). Savage et al. (2005) associate senses of belonging in particular with city centers with "high culture", cultural activities and shopping, however as an exclusive and selective activity. Aloof from everyday routines, the activities performed in the city center mark the escapistic trait of the site. However, even though the center itself is uncontested, this does not hold true for the uses, the meanings and functions affiliated with the center. The changing meanings associated with the center of a city refer to the second principle of heterotopias.

\subsection{Second Principle: Cultural Synchrony}

"The second principle of this description of heterotopias is that a society, ... can 
make an existing heterotopia function in a very different fashion; for each heterotopia has a precise and determined function within a society and the same heterotopia can, according to the synchrony of the culture in which it occurs, have one function or another" (Foucault, 1986: p. 25).

The second principle of heterotopias is represented in the changing meanings of the city center marked by its transformation from the functional center into a place of symbolic representation of the cultural heritage, identity and belonging. The city center has ever since been perceived as the center of the city not just in Cartesian coordinates. It is the meaning and the function of a "center" that makes a place "central". Following the second principle of heterotopias the meanings making the city center the center of the city have morphed over time in synchrony with the prevailing culture that shaped the dispositif imposed on the city center. The dispositif of the city center used to be and still is continuously negotiated and contested.

The cultural re-presentation of the Historic City Center goes back to the time when Vienna developed as the capital of the Austrian Hungarian Monarchy, an empire comprising more than 50 million inhabitants. With the end of the Austrian Hungarian Monarchy the cultural production of Vienna's glorious past was history. When modernist urban planning schemes dominated, the Historic City Center was out of the focus of urban planners. Since the 1970s the production of a livable historic city center, focusing on the ambient qualities as a signifier of the cultural heritage and symbolic (corporate) identity of the city has come to the fore. The visual representations of Vienna's "glorious past" became the narrative and the myth, the cultural re-production of the Historic City Center is built upon at the turn of the Millennium. Following the notions of the symbolic economy "Vienna, the imperial city" or "Vienna the world capital of music" became the unique selling propositions of the city. At that time the city center was incrementally being posed under preservation orders, transforming the meaning of the city from the functional center to a museum's backdrop. Visual strategies and the aesthetization of the public realm have extended over time by performing urban culture. The transformation of the historic city center towards a heterotopia of belonging does not only imply the transposition of meanings. Each step has been accompanied by approaching the traits that delineate the principles of heterotopias and has to be dissected in that contextualization. The stages of transformation are overlapping and interlinked with each other.

The transformation of the Historic City Center into a perfected site of representations of belonging presupposed tightened regulations. As these regulations do not address the other sites of the city, this makes this place-according to the traits of heterotopias-distinctive from everyday spaces unrevealing the site as the highest regulated place within the city, and, eventually meeting the traits of the third principle of heterotopias. 


\subsection{The Third Principle: A Highly Regulated Microcosm}

In the third principle Foucault points at two essential traits of Heterotopias:

1) the capability of juxtaposing in a single real place several spaces, several sites that are in themselves incompatible (Foucault, 1986: p. 25), and

2) the description of Heterotopias as highly regulated places onto which the whole world comes to enact its symbolic perfection. These heterotopias are sacred places but "even a sort of happy, universal heterotopia" (Foucault, 1986: p. 26). In this vein Foucault denotes the theater bringing onto the stage, one after another, "a whole series of places that are foreign to one another", just as the superimposed meanings of the traditional Persian garden: “... a sacred space supposed to bring together inside its rectangle four parts representing the four parts of the world ... [by its vegetation] ... with a even more sanctified place in the center represented by a fountain or spring ... in a sort of microcosm" (Foucault, 1986: p. 25).

In its microcosm the historic city center puts together all the functions that make up a "typical" city: Work, living, governmental and administrative functions, culture, recreation, shopping, leisure and entertainment. Functionally-specific spatial units have developed, indicating a certain kind of their incompatibility to each other.

Dissecting the traits and transformations of the functionally specific spatial units reveals that in contrast to the remaining spaces outside the old city the functions represented in these spatial quarters do not only display functional and spatial perfections of the dominant uses but even the transformation of these functions and their related spatial representations transpose the urban form and its functions towards what was regarded an approximately universal form of heterotopias by Foucault. The functionally divided spatial units have developed around St. Stephen's Cathedral, in the first place marking the sacred site in the center of the city core, however, its meaning has morphed into a sacred symbol of identity and belonging not only of Vienna but of the entire Austrian nation as well.

The main shopping district is represented by outlets of internationally operating upscale chain stores that can neither be found in other parts of the entire city nor in other cities or retail agglomerations in the whole country. Strategies of urban planners and retail businesses are working together. The representative facades of the monument protected historic buildings provide a perfect scenery of a shopping environment in accordance to the idealized vision of a flâneur, by itself an urban myth and utopia (Shields, 1994). The most recent refurbishment by the city has exclusively been aimed at improving the ambience of the main shopping district. The old fashioned downtown areas approach the concept of shopping malls, following the visions of controlled diversity, mixed or multiuse city centers and the logic of inclusion and incitement. Store fronts have as well become the focus of monument protection and landmark preservation. A shopping mall-like ambience of safety, cleanliness, and "the soothing lightning, the 
polished surface $\ldots$ and enticing displays, where [nothing] ... can disturb the illusion of a harmonious world" (Kohn, 2001: p.76), has been imposed on the Historic City Center.

The observed transformation indicates a widening gap between "everyday" spaces and the exclusive traits of universal sites of belonging enhanced by the exclusivity of the shopping environment and of the shops themselves-about $80 \%$ of sales area in the main shopping area account for exclusive "Fashion \& Style" outlets and $80 \%$ of the sales area are operated by international chain stores (see Hatz, 2010). Even though considered as a thorough capitalization and privatization of the public realm of the city center, "This ... defines the center as a place that one visits for 'special' reasons and which is thereby set apart from the routines of daily life. Rather than urban centrality, with the core being the essential hub of life, this denotes a rather different meaning of the city center in which it is available for special purposes, but the day-to-day business of life goes on elsewhere" (Savage et al., 2005: p. 116). By installing globalized retailers behind the monument protected facades of the shops, the main shopping district simulates a diversified traditional local shopping environment, inverting and contradicting the standardized and homogenized reality of spaces of consumption. The exchange value in terms of rents for retail premises underlines the distinctiveness of the city center from the remaining shopping environments in the city. Rents for retail space in the historic city center have climbed up to $400 €$ per square meter, more than three times above the rates for the most expensive retail space in shopping centers, amounting to $120 €$ per square meter (EHL, 2018).

The governmental district is characterized by the "headquarters" of government and city administration, represented by the offices of the President as well as of the Chancellor of the Republic of Austria. Most of the ministries are concentrated in the immediate surroundings and the same holds true for the city administration, represented by the city hall. The cultural district is shaped by a concentration of museums, theaters and concert halls, most of them dedicated to the performance and production of high culture. Encompassing the tangible and intangible cultural heritage of the city and the entire country they represent a perfected form of what is considered as the country's and the city's culture, heritage and identity and relate to Savage's notion on the seminal meaning of high culture for evoking senses of belonging. The transformation of the city center as a perfected re-presentation of belonging, however, implies a set of regulations for enacting symbolic perfection.

Just like the Persian garden the Historic City Center has indeed been transformed into the most highly regulated place within the entire city, approximating a universal form of heterotopia. In the course of burgeoning cultural and symbolic economies regulations in particular on the visual coherence have been tightened since the 1970s. Aesthetic qualities and a "good atmosphere" of urban environments are essential for provoking emotions and evoking senses of belonging (see Savage et al., 2005). Means of imposing visions of cultural identity 
mainly concentrate on visual strategies at first in order to preserve and protect the visual coherence of the Historic City Center. Not affected by respective regulations for 70 years, since the 1970'ies, however, the urban form of the Historic City Center has increasingly been placed under a preservation order, excluding influences of modern architecture. The regulations established since then display a tightening of control over the Historic City Center, a downscaling of control and an extension of the area affected by measures supervising the visual coherence.

In 1972 the Amended Law on Old Town Conservation was passed. A further amendment in 1978 enabled the Landmark Preservation Board not just to protect a single building but an entire group of buildings if designated as a valuable historic, not modern, architectural-ensemble. The entire Historic City Center has been designated as a "protected zone", comprising about more than 1700 protected structures, 1200 of which residential. Any alterations of the physical structure of the buildings within the designated area have to be assigned to planning commissioners, in particular to architects and art historians. The zoning codes have been refined by limiting the maximum height of the single buildings to the present status quo, a measure originally aimed at closing down options for investors, building owners and developers with regard to converting attics into additional residential or office spaces. In addition, the open spaces (courtyards, green spaces) within the single buildings have become subject to protection, which even refers to landscaping. Since the most recent amendment public parks have been designated as landmarks as well. Under the laws of monument protection public spaces like the lawns of the public gardens have become "privatized" by the public sector.

In 2001 the Historic City Center was designated as World Cultural Heritage, implementing another layer of regulation, now spreading over the entire city and legitimized by the "supra-national" authority of the UNESCO. The core zone of the World Cultural Heritage site is surrounded by a buffer zone extending into the adjacent districts. Regulations on preservation were supplemented by means of display and performance when sight axes and sight lines were incorporated. Sight axes and sightlines providing undisturbed views of the Historic City Center are now determining urban development projects all over the entire city. New developments like new office centers and high rises have to be adjusted according to these sight axes. Producing "universal" spaces of belonging by aesthetization, visual conformity and controlled diversity has become overwhelming and the force of law (Zukin, 1995: p.123f.) by an overall design concept.

The third principle of heterotopias, targeting their capability of juxtaposing incompatible sites at one place has been extended to architectural styles and integrated in the third principle of heterotopias as highly regulated places. The operational guidelines of the UNESCO for the Historic Center of Vienna are based on an overall design concept, “... building on medieval tradition and developing into an instantly recognizable Austrian form of Baroque culture, a Viennese 
Gründerzeit idiom, and a Viennese modernity, all of these styles aspiring to meet the challenges of a Gesamtkunstwerk..." (ICOMOS, 2001: p. 1). Design standards, architectural and aesthetic guidelines are downscaled to regulate every single detail of the visual coherence: "This ... applies ... to the modification of the existing buildings, with special attention paid to the preservation of the outward appearance, character and style of the building and in particular its scale, rhythm, proportions, technological equipment and colour scheme..." (Stadtentwicklung Wien, 2006: p. 101). “All architectural intervention projects [in the historic city center] are primarily evaluated and reviewed by Municipal Department 19 (MA 19)-Architecture and Urban Design. This relates to new structures, additions and refurbishments including e.g. penthouse or loft projects, shop entrances, advertising installations, window replacements, etc." (Stadtentwicklung Wien, 2006: p. 99). Yet, the vision of a mixed-used old-fashioned city center was considered worth preserving. Designating neighborhoods of the Historic City Center as protected residential areas added another layer of regulation by preventing the conversion of apartments for other uses. By the detailed tightened regulations for the entire Historic City Center a programmatic convergence of the historic city center and heterotopias as highly regulated places becomes unfolded.

The shift from protecting and preserving the setting of the Historic City Center in terms of a museum backdrop towards a perfect and universal place of belonging by performing cultural identity was achieved by introducing another layer of regulation. The "Illumination Masterplan for Vienna" was passed in 2007, putting a comprehensive illumination concept over the City Center, regulating the design of the street lamps and how a structure has to be illuminated. Public and private illumination concepts of the outward appearance have to follow this masterplan. The Illumination Masterplan as well as tightened regulations, demonstrate "the ... organizational power of planning regulations and design controls that can turn the material form of the city to any successful ... magic show ... where illusion is produced ..." (C. Boyer cit. in Miles \& Miles, 2004). The "magic show" and illusion, contradicting everyday urban spaces accentuates the "otherness" of the Historic City Center, by this, converging to a perfect place of identity and belonging.

Re-presentations of cultural performances of high culture concentrated in the city core even mark the city center a "happy place". The trait of a "happy place" is enhanced by a growing number of spots for leisure and relaxation like restaurants and bars, a development fostered by recent planning strategies (see Hatz, 2010). At the banks of the River Danube Canal a vivid "Waterfront Development" has been established, comprising leisure facilities like artificial beaches or a bathing ship. The proliferation of these facilities has not been completed yet. Following the logic of the cultural and symbolic economies just as the economies of experiences cultural institutions are expanding just as public spaces have become integrated in the proliferation of an all the year round festival. The festiva- 
lization of the city center, in compliance with the preservation of the historic look and feel of the city center and expanding cultural institutions point at the forth principle of heterotopias.

\subsection{The Fourth Principle: Heterochronies}

The fourth principle links heterotopias to slices in times in terms of "heterochronies". Foucault identifies heterotopias linked to an infinitive accumulation of time like museums or libraries. The historic city center encloses the most distinguished museums tied to Vienna's and Austria's history and cultural heritage-each of which a highly heterotopic place by itself, but even architectural symbols connected to Vienna's and all of Austria's past. By designating the entire historic city center as a protected zone and UNESCO-World Cultural heritage, the place has been morphed into a monument and museum by itself. What is increasingly criticized by urban scholars and urban planners, unfolds as a burgeoning trait of heterotopias. Since the 1990's cultural institutions such as museums, theaters or concert halls have expanded in the Historic City center. Theaters and Opera Houses are re-dedicated to performances of high culture and public spaces are designated as "art places". In 2000 the "Museums Quartier" was opened replacing the former use as an exhibition hall for national and international fairs and now being one of the 10 largest Museum complexes world-wide. By new cultural institutions like the "House of Music" or the "Mozarthaus Vienna", all referring to the city's high culture and established after the turn of the millennium, the city center approaches its perfection as a heterotopia linked to accumulation in time, enhances its distinctiveness to other urban sites, and, by linking to high culture "purifies" its traits as a "universal" site of belonging.

Contrary to heterotopias that "enclose in one place all times, all epochs, all forms, all tastes, the idea of constituting a place of all times that is itself outside of time and inaccessible to its ravages...” (Foucault, 1986: p. 27), Foucault delineates absolutely temporal heterotopias, linked "to time in its most flowing, transitory, precarious aspect, to time in the mode of the festivals" (Foucault, 1986: p. 27). In the rationale of Foucault these two forms of heterotopias, "the heterotopia of the festival and that of the eternity of accumulating time" (Foucault, 1986: p. 27) are not mutually exclusive but might come together at one real place. The Historic City Center seemingly provides the perfect scenery for the "all year round festivalization" that has not only enhanced the third principle of the Heterotopia "City Center" as a "happy place" but also is an integral part of the cultural and symbolic economies. In the city center, festivals and events are expanding at a temporal and spatial axis. Public spaces are taken away from the public but returned as a commercialized, controlled and ordered experience. The square in front of the Vienna city hall has increasingly become "a controlled experience", i.e. has become occupied by events, festivals or respective preparations all year long (see Hatz \& Kreppenhofer, 2012). Public squares like "Karlsplatz" or 
"Ringstraßen-Boulevard" are becoming integrated in the growing number of festivals and performances. By accumulating the traits of the first four principles of heterotopias and their transposition onto the city center as "universal" symbol of belonging, an apparatus of inclusion and exclusion is established. Inclusion and exclusion in and of the public realm by "soft", intangible means seemingly evolve as a characteristic trait of "universal" spaces of belonging and point at the fifth principle of heterotopias.

\subsection{The Fifth Principle: Openings and Closings}

In the discourse on public space and the privatization of public spaces the dialectic of inclusive and exclusive practices has moved in the focal point. In the fifth principle Foucault denotes heterotopias as not as freely accessible as public spaces and points at tangible as well as intangible mechanisms of openings and closings of these spaces. "Heterotopias always presuppose a system of opening and closing that both isolates them and makes them penetrable" (Foucault, 1986: p. 26). These mechanisms relate to rites for entering these (sacred) places where a certain kind of (religious) purification is the common denominator.

For the city center these mechanisms of openings and closings can take various forms and stretch to a "purification" of the place in terms of a perfected place of cultural identity and belonging. When in gated communities the mechanisms of openings and closings are physically re-presented by walls, fences, gates and guards, having taken control over the isolation and penetrability of these spaces, historic city centers are freely accessible public spaces. Openings and closings in terms of inclusion and exclusion concentrate on intangible-soft means of gating the space and encompass a broad spectrum of architecture, uses, functions and social design that is in compliance with a purified and perfected utopia of the historic city.

The inclusive and exclusive apparatus of the city slightly excludes or replaces tangible just as intangible re-presentations, that are not in compliance with a "perfected" place of belonging, but this apparatus includes and enhances uses, functions and modifications of the urban form that transform the place according to the principles of heterotopias, as "real and unreal urban spaces ... onto which the whole world comes to enact its symbolic perfection" (Foucault, 1986: p. 24). The system of inclusion and exclusion has to be read in its relational function. It aggravates the exclusivity of the place in relation to the other urban precincts. By this means, the historic city center becomes more and more disconnected from the "ordinary", normal and everyday spaces. According to the notions of Savage et al. (2005), the accentuation of this "otherness", corresponds to the traits of "universal" spaces of belonging. In context to the synchrony of culture, meanings and representations of belonging are ephemeral and volatile constructs. As a (spatial) mediator of the prevailing urban culture the city center reflects the prevailing utopias of belonging and spatial representations as a reflection of the near and the far order of urban society (see Lefebvre, 1996: 
p.100ff.) that can be identified by the most recent transformation of the city center.

Various layers of regulations on the visual coherence do not only generate a filter of closing by excluding influences of modern architecture. What is more, it closes down options of private businesses and entrepreneurs. Adapting the building fabric according to the demands of the globalized economies has resulted in uncertainty of costs and unexpected delays. Work places and headquarters of leading companies relocate as the strict regulations on the ambient quality do not meet the demands of globalized economies anymore. Government departments and offices of the city administration are leaving, giving way to functions and uses that accentuate the strategic role of the city center as an exclusive and perfected space of belonging. Cultural institutions and event locations are moving in or expanding spatially and by their numbers. Office spaces that were left by governmental institutions are now occupied by an increasing number of luxury hotels and exclusive shops for conspicuous consumption (see Hatz, 2009). In addition to the growing number of bars and upscale restaurants the city center morphs into a space of eternal holidays, as it is one of the characteristic traits of heterotopias (Heynen, 2005: p. 313) and implicitly makes the space even more distinctive to the normal everyday spaces. In this vein, the historic city center approaches the traits of "universal" spaces of belonging, however, re-presenting the characteristics of the prevailing urban culture that is marked by romanticized visions of historic urban ambiences, walkable, clean and safe, hence an inversion of the experienced normal everyday spaces. Consumption and capitalization of culture as characteristic traits of urban societies (e.g. Zukin, 2005) manifest themselves not only in the globalized spaces for conspicuous consumption but in the consumption of the space itself. "Universal" spaces of belonging are strongly related to the consumption of these spaces, indicating that senses of belonging are related with the consumption, even the consumption of emotions.

The apparatus of opening and closing, of inclusion and exclusion unfolds as means of power and technology of power, even in order to remove anything that can disturb the magic show of a historic city center. By re-interpreting a passage leading to art-place "Karlsplatz" as art-passage, a new illumination concept and the display of art and art installations were to provide an ambience attractive to a "flâneur" and to design out the rough urban edges, like a highly visible drug scene. Shop owners will have to vacate their stores giving way to re-presentations of culture. The recent amendment of Vienna's law on safety and security regulations, in force since March, 2010, authorizes police forces to remove any individuals suspected of showing socially deviant behavior, like beggars or drunks, from public space (see Wiener Landes-Sicherheitsgesetz). The production of ambient qualities has incorporated the "social design" of the ambience. By evoking "controlled" emotions power can be exerted over behavior and minds. Urban design evolves as a technology of designing emotions. By the prevailing 
power of the ambient quality the meaning of the city center as the functional center of the entire city is weakening. Now the urban functions follow the urban form-in this vein, a heterotopia of belonging.

\subsection{The Sixth Principle: A Relational Conclusion}

In the sixth principle heterotopias are described as spaces having a function in relation to all the remaining space. Foucault explicitly focuses on the illusionary character of heterotopias and the function of heterotopias in their "otherness" in terms of perfected, meticulous, well-arranged and organized places, opposite to the messy, ill-constructed and chaotic, normal, everyday and ordinary spaces. These heterotopian places expose every real space, all the sites inside of which human life is partitioned. In this line Foucault refers to the colonies either established by the English Puritans in America or those of the Jesuits in South America. Strict regulations, not only of the daily life but of the spatial layout of these communities as well, were to achieve perfection of the humans, society and a perfected form of these "other" places (Foucault, 1986: p. 27). Connections can be made to the synchrony of recent prevailing urban culture that transposes the historic city center into a highly regulated "other" place. By symbolizing a perfected place of belonging it exposes and inverts the remaining spaces in the city.

The relational meaning of heterotopias is reflected in the notes of Savage et al. (2005), identifying relations of meanings, emotions and perception as seminal in the constitution of senses and feelings of belonging. These relations are spanned between the two poles of everyday spaces and specific exclusive other places. Not to be in these places, but the (emotional) space settings and the settings of relations to these specific places evoke sentiments of belonging. The transformation of the historic city center has to be read in the context of recent urban developments. Following the notions of Sloterdijk (2004), the recent urban forms are morphing into Foam Cities. The emerging Foam Cities consist of "spheres"-emotional space settings, enabling city dwellers to perform their individualized lifestyles. In recent urban developments, redeveloped brown field areas, gentrified neighborhoods, themed privatized communities but even themed shopping environments might be considered as such spheres. The spheres are loosely interconnected by (virtual) communication technologies, enabling the city dwellers to shift easily between the particular spheres. When being transferred to recent urban developments, the spheres might be virtually located in a matrix, spanned by spaces for work, housing, leisure and collective assemblies e.g. for meeting friends, socializing, events and festivals. For the City of Vienna a transformation towards an emerging "Foam City" is marked by the urban development plan in effect at present (Stadtentwicklung Wien, Magistratsabteilung 18, 2005), not a spatially comprehensive plan for the entire city, but designating 13 "target areas", each of which dedicated to a specific "theme". The city center is one of these "themes".

In this relation of space settings, the historic city center serves as a signifier of 
belonging, connecting the different spheres by its overarching meanings as "universal" symbol of belonging of and with the entire city. In commodified and even privatized urban environments these meanings are becoming essential. New urban centers, tied to the global economies, promote their location not only by their short time-distance relation to the airports, but also by their short time-distance relation to the historic city center. And, even though not spatially located within the historic city center, related to time distance, they are. In this vein, the historic city center inverts recent urban development. However, as a heterotopia of belonging the historic city center is inextricably linked to the other spaces in emerging Foam Cities just like other spaces inextricably linked to a "universal symbol of belonging", as represented by the heterotopias city center.

\section{Conclusion}

In postmodern urban environments commodified and privatized urban spaces have become "products" like consumer goods. Scholars (e.g. Hellmann \& Zurstiege, 2008; Savage et al., 2005; Zukin, 2005) agree on the seminal meaning of consumption in recent individualized urban societies for the construction of the self and self-identity. In this vein the consumption of urban spaces has become part of the construction of identity. In contrast to most of the recent discourses on commodification and privatization of the public realm of cities, Foucault's concept of heterotopias goes at least one step beyond and delineates the intrinsic meanings of heterotopias for urban society and its spatiality that might be capitalized or not. In the research on heterotopian spaces, either in themed planned communities or gated communities (e.g. Bartling, 2005; Low, 2005) the intrinsic function of marketing strategies in terms of an "illusionary reversion of the everyday" (Heynen, 2005: p. 313) unfolds. "The combination of spatial and marketing strategies ... qualifies these spaces as heterotopias" (Heynen, 2005: p. 313). The capitalization of heterotopias is one of the signifiers of their exchange value (see Lefebvre, 1996: p. 66) for urban society and it is a means among others for performing the traits of heterotopias as "other places".

The study identifies Foucault's concept of heterotopia as an appropriate èpistemé for reading and understanding the urban form of Vienna. However, as the study explicitly focuses on the city of Vienna, future research aimed at testing Foucault's concept of heterotopia as an èpistemé for reading the urban form has to be dissected by applying the concept to other European Cities and to cities of the Western Hemisphere. There is no doubt that in other parts of the world cities and urban forms face different challenges and as a future issue for urban scholars the analysis suggests testing Foucault's concept in different urban environments. In particular the growing interest in assemblage theory (De Landa, 2016; McFarlane, 2011) for reading the urban form provides a promising field for future research and points at fruitful connections between Foucault's concept of heterotopias and assemblage theory for a better understanding of postmodern "Foam cities". 


\section{Conflicts of Interest}

The author declares no conflicts of interest regarding the publication of this paper.

\section{References}

Allen, J. (2006). Ambient Power: Berlin's Potsdamer Platz and the Seductive Logic of Public Spaces. Urban Studies, 43, 441-454. https://doi.org/10.1080/00420980500416982

Augé, M. (2008). Non-Places. London, New York: Verso.

Bartling, H. (2005). A Master-Planned Community as Heterotopias. The Villages, Florida. In M. Dehaene, \& L. De Cauter (Eds.), Heterotopia and the City. Public Space in a Postcivil Society (pp. 165-178). London, New York: New Routledge.

Beck, U., Giddens, A., \& Scott, L. (1995). Reflexive Modernization. Politics, Tradition and Aesthetics in the Modern Social Order. Cambridge: Polity Press.

Chambers, I. (1990). Border Dialogues. Journeys in Postmodernity. London, New York: Routledge.

Christiaanse, K. (2002). Die Stadt alsLoft. [The City as Loft.] Topos, 38, 6-17.

CIAM (Congress Internationaux d'Architecture moderne) (1933). La Charte d'Athenes or the Athens Charter, 1933 (J. Tyrwhitt Trans.). Paris, France: The Library of the Graduate School of Design, Harvard University.

Dahlmanns, C. (2008). Die Geschichte des modernen Subjekts: Michel Foucault und Norbert Elias im Vergleich. Münster: Waxmann.

De Landa, M. (2016). A New Philosophy of Society. Assemblage Theory and Social Complexity. Edinburgh: Edinburgh University Press.

Dehaene, M., \& De Cauter, L. (2008b). Heterotopia in a Postcivil Society. In M. Dehaene, \& L. De Cauter (Eds.), Heterotopia and the City. Public Space in a Postcivil society (pp. 3-9). London, New York: Routledge.

Dehaene, M., \& De Cauter, L. (Eds.) (2008a). Heterotopia and the City. Public Space in a Postcivil Society. London, New York: Routledge.

Der Spiegel (1991). Max Frisch. Der Spiegel, 15, 264-265.

EHL Immobilien GmbH (2018). Wir leben Retail. Geschäftsflächenbericht Österreich. https://www.ehl.at/de/marktberichte\#berichtbestellen

Foucault, J. M. (1986). Of Other Spaces (Miskowiec, J. Trans.). Diacritics, 16, 22-27. https://doi.org/10.2307/464648

Gehl, J. (2011). Life between Buildings: Using Public Space. Washington, Covelo, London: Island Press.

Hatz, G. (2009). Kultur als Instrument der Stadtplanung. In G. Hatz, \& H. Fassmann (Eds.), Wien-Städtebauliche Struktur und gesellschaftliche Entwicklungen (pp. 299-336). Wien: Böhlau. https://doi.org/10.7767/9783205119326-010

Hatz, G. (2010). Eine Frage des Stils. Die Transformation der Wiener City zum Life Style Center. Berichte des Arbeitskreises Geographische Handelsforschung, 28, 25-30.

Hatz, G., \& Fassmann, H. (2006). Urban Renewal in Vienna. In V. Szirmai (Ed.), Social Changes and Social Sustainability in Historical Urban Centres (pp. 218-236). Centre for Regional Studies of Hungarian Academy of Sciences.

Hatz, G., \& Kreppenhofer, A. (2012). Zielgebiet City: Planung Prozess Leitbild (p. 18). Wien: Magistratsabteilung. 
Hebbert, M., \& Sonne, W. (2006). History Build the Town: On the Uses of History in Twentieth-Century City Planning? In J. Monclus, \& M. Guardia (Eds.), Culture, Urbanism and Planning (pp. 9-19). Aldershot: Ashgate.

Hellman, K. U., \& Zurstiege, G. (2008). Räume des Konsums. Wiesbaden: Verlag für Sozialwissenschaften.

Hetherington, K. (1997). The Badlands of Modernity. Heterotopia and Social Ordering. London \& New York, NY: Routledge. https://doi.org/10.4324/9780203428870

Heynen, H. (2005). Heterotopia Unfolded? In M. Dehaene, \& L. und De Cauter (Eds.), Heterotopia and the City. Public Space in a Postcivil Society (pp. 311-323). London, New York, NY: Routledge.

ICOMOS (2001). Vienna (No. 1033). http://whc.unesco.org/archive/advisory_body_evaluation/1033.pdf

IFES (2009). City-Befragung. Tabellenband, Wien: Institut für empirische Sozialforschung.

Immopreisatlas.at (2018).

Kohn, M. (2001). The Mauling of Public Space. Dissent, 48, 71-77.

Leceese, M., McGormick, K., \& Congress for the New Urbanism (2000). Charter of the New Urbanism. New York, NY: McGraw-Hill.

Lefebvre, H. (1996). Writing on Cities. Cambridge, Oxford: Blackwell Publishers.

Low, S. (2005). The Gated Community as Heterotopias. In M. Dehaene, \& L. De Cauter (Eds.), Heterotopia and the City. Public Space in a Postcivil Society (pp. 153-164). London, New York, NY: Routledge.

McFarlane, C. (2011). The City as Assemblage: Dwelling and Urban Space. Environment and Planning D: Society and Space, 29, 649-671.

Miles, S., \& Miles, M. (2004). Consuming Cities. London, New York, NY: Palgrave Macmillan. https://doi.org/10.1007/978-0-230-80264-3

Novy, A., Redak, V., Jaeger, J., \& Hamedinger, A. (2001). The End of Red Vienna. Recent Ruptures and Continuities in Urban Governance. European Urban and Regional Studies, 8, 131-144. https://doi.org/10.1177/096977640100800204

Oswalt, P. (2006). Shrinking Cities 2. Interventions. Ostfildern: Hatje Cantz.

PlØger, J. (2008). Foucault's Dispositif and the City. Planning Theory, 7, 51-70. https://doi.org/10.1177/1473095207085665

Savage, M., Bagnall, M., \& Longhurst, M. (2005). Globalization \& Belonging. London: Sage Publications.

Shields, R. (1994). Fancy Footwork: Walter Benjamin's Notes on Flânerie. In K. Tester (Ed.), The Flâneur (pp. 61-80). London, New York, NY: Routledge. https://doi.org/10.4324/9780203420713_chapter_4

Siret, D. (2006). Le Corbusier Plans. 1940 Studies in Sunlight (No Place). Paris: Fondation Le Corbusier. https://halshs.archives-ouvertes.fr/halshs-01249648/document

Sloterdijk, P. (2004). Sphären 3: Schäume. Frankfurt/Main: Suhrkamp.

Soja, E. (1996). Thirdspace: Journeys to Los Angeles and Other Real-and-Imagined Places. Oxford, Cambridge: Blackwell Publishers Ltd.

Soja, E. (2000). Postmetropolis: Critical Studies of Cities and Regions. Oxford: Blackwell Publishers Ltd.

Stadtentwicklung Wien, Magistratsabteilung 18 (2005). STEP05. Stadtentwicklung Wien 2005. Linz: Friedrich Vereinigte Druckereien und Verlagsgesellschaft. 
Stadtentwicklung Wien, Magistratsabteilung 18 (2014). STEP2025. Stadtentwicklungsplan Wien. Wien: Magistratsabteilung 18 Stadtentwicklung und Stadtplanung.

Stadtentwicklung Wien, Magistratsabteilung 19, Architektur und Stadtgestaltung (2006). Wien, Weltkulturerbe: Der Stand der Dinge. Wien: Magistratsabt 19, Architektur und Stadtgestaltung.

Statistik Austria (2011). Registerzählung 2011. Beschäftigte in der Arbeitsstätte. http://www.statistik.at

Vorauer, K., \& Matznetter, W. (2009). Sozialer Wohnbau. In G. Hatz, \& H. Fassmann (Eds.), Wien-Städtebauliche Struktur und gesellschaftliche Entwicklungen (pp. 245-269). Wien: Böhlau.

Wiener Landes-Sicherheitsgesetz. http://www.wien.gv.at/recht/landesrecht-wien/rechtsvorschriften/pdf/i1100000.pdf

Wigley, M. (2001). The Great Urbanism Game. Architectural Design, 41, 8-11.

Zukin, S. (1995). The Culture of Cities. Oxford: Blackwell Publishers.

Zukin, S. (2005). The Point of Purchase: How Shopping Changed American Culture. London: Routledge.

Zukin, S. (2010). Naked City: The Death and Life of Authentic Urban Places. New York, NY: Oxford University Press. 